\title{
Kajian Perencanaan Jaringan Long Term Evolution (LTE) Pada Node B 4G di Kota Tangerang Selatan
}

\author{
Study on Long Term Evolution (LTE) Network Planning at 4G Node B in South \\ Tangerang City \\ Rummi Sirait ${ }^{1}$, Rizka Fadhila Dhuha ${ }^{2}$ \\ ${ }^{1,2}$ Fakultas Teknik, Universitas Budi Luhur \\ Jl. Ciledug Raya, Petukangan Utara, Kebayoran Lama, Jakarta Selatan 12260 \\ e-mail: ${ }^{1}$ rummi.sirait@budiluhur.ac.id, ${ }^{2} 1552500355 @$ student.budiluhur.ac.id
}

\begin{abstract}
Abstrak
Kualitas jaringan Long Term Evolution (LTE) di Kota Tangerang Selatan masih kurang optimal, berdasarkan data hasil drive test nilai rata-rata RSRP dan SINR termasuk dalam kategori buruk. Hal tersebut dikarenakan jumlah site yang masih kurang, serta gedung-gedung yang menghalangi site. Perlu dilakukan perencanaan ulang untuk meningkatkan kinerja jaringan LTE di Kota Tangerang Selatan dengan melakukan perhitungan estimasi jumlah penduduk serta pengguna seluler pada tahun 2024, untuk mengetahui jumlah site yang dibutuhkan yang mencakup seluruh area di Kota Tangerang Selatan. Nilai total loss yang disebabkan oleh gedung-gedung di wilayah Kota Tangerang Selatan juga diperhitungkan, dengan menggunakan perbandingan model propagasi COST 231 dan Lee, sehingga didapatkan prediksi cakupan site serta jumlah site yang dapat mencakup keseluruhan area. Hasil yang didapatkan dari perencanaan jaringan 4G LTE di Kota Tangerang Selatan pada eNodeB berdasarkan kapasitas dari nilai parameter RSRP dan SINR termasuk dalam kategori sangat baik. Sedangkan berdasarkan coverage menggunakan model propagasi COST 231 dan Lee, didapatkan model propagasi Lee yang sesuai dengan parameter serta mencakup area lebih luas dibandingkan model propagasi COST 231. Dari keseluruhan hasil simulasi untuk nilai RSRP dan SINR sudah sesuai dengan standar KPI, yaitu nilai RSRP > $80 \mathrm{dBm}$ dan nilai $\mathrm{SINR}>5 \mathrm{~dB}$.
\end{abstract}

Kata kunci: LTE, Propagasi Cost 231, Propagasi Lee, RSRP, SINR

\section{Abstract}

The quality of the Long Term Evolution (LTE) network in South Tangerang City is still less than optimal, based on data from drive test result, the average value of RSRP and SINR is in the poor category. That is because the number of sites that are still lacking, and the buildings that block the site. Replanning needs to be done to improve the performance of LTE networks in South Tangerang City by calculating the estimated population and cellular users in 2024, to find out the number of sites needed that cover all areas in South Tangerang City. The value of total loss caused by buildings in the South Tangerang City area is also calculated, using a comparison of the COST 231 and Lee propagation models, so that a prediction of site coverage and the number of sites that can cover the entire area is obtained. The results obtained from $4 G$ LTE network planning in South Tangerang City on eNodeB based on the capacity of the RSRP and SINR parameter values are included in the very good category. Whereas based on coverage using the COST 231 and Lee propagation models, Lee's propagation model is obtained that matches the parameters and covers a wider area than the COST 231 propagation model. From the overall simulation results for RSRP and SINR values are in accordance with the KPI standard, namely the RSRP value $>-80 \mathrm{dBm}$ and SINR value $>5 \mathrm{~dB}$.

Keywords: LTE, Cost 231 Propagation, Lee Propagation, RSRP, SINR 


\section{PENDAHULUAN}

Peningkatan area jangkauan jaringan telekomunikasi teknologi 4G Long Term Evolution (LTE) harus senantiasa dilakukan, mengingat kebutuhan dan jumlah pengguna (user) yang mengalami peningkatan. Pada daerah urban dengan pembangunan gedung-gedung bertingkat serta tingkat pertumbuhan pengguna jaringan yang tinggi menyebabkan layanan telekomunikasi yang didapatkan user menjadi kurang optimal. Hal ini dapat disebabkan karena perencanaan sel kurang optimal dari segi coverage serta capacity. Teknologi LTE merupakan layanan yang mempunyai kemampuan tinggi dalam sistem komunikasi bergerak yang merupakan langkah menuju generasi ke-4 (4G) dari teknologi radio yang dirancang untuk meningkatkan kapasitas dan kecepatan jaringan telepon bergerak[1],[2].

Implementasi teknologi LTE di Indonesia masih belum menyeluruh dan baru diterapkan di beberapa kota besar saja, namun frekuensi untuk menggelar LTE sudah disediakan, salah satunya pada frekuensi $1800 \mathrm{MHz}$. Sebelum menggelar teknologi LTE perlu dilakukan perencanaan jaringan untuk mengetahui jumlah eNodeB yang dibutuhkan [1].

Penelitian ini akan mengkaji tentang perencanaan jaringan 4G di Kota Tangerang Selatan, dimana berdasarkan hasil drive test yang dilakukan dibeberapa kelurahan Kota Tangerang Selatan ini masih memiliki nilai Signal Interference to Noise Ratio (SINR) dan Reference Signal Received Power (RSRP) yang buruk. Hal ini dikarenakan letak Base Transciever Station (BTS) yang cukup jauh, sehingga tidak tercakup keseluruh wilayah dan juga dikarenakan adanya halangan atau Non Line Of Sight (NLOS) serta jumlah pengguna yang semakin meningkat. Jumlah penduduk di wilayah Kota Tangerang Selatan cukup padat sehingga perlu perencanaan ulang untuk mendapatkan kualitas jaringan yang baik untuk 5 tahun ke depan. Untuk simulasi perencanaan ulang jaringan $4 \mathrm{G}$ dilakukan dengan menggunakan software ATOLL.

\section{METODOLOGI PENELITIAN}

Perencanaan jaringan pada penelitian ini bertujuan untuk mengoptimalkan jaringan 4G LTE di Kota Tangerang Selatan, perencanaan dilakukan berdasarkan kapasitas dan coverange. Perencanaan jaringan 4G LTE di Kota Tangerang Selatan diawali dengan mengumpulkan data jaringan eksisting dengan melakukan drive test di wilayah Kota Tangerang Selatan, kemudian dilakukan analisis terhadap hasil drive test untuk menentukan apakah perlu dilakukan perencanaan ulang. Berdasarkan data eksisting, perencanaan dilanjutkan dengan memperkirakan berdasarkan kapasitas dan coverage dengan membandingkan dua model propagasi Cost 231 dan Lee. Setelah itu dilakukan simulasi menggunakan software ATOLL 3.3. Diagram blok sistem perencanaan jaringan 4G di Kota Tangerang Selatan ditunjukkan pada gambar 1.

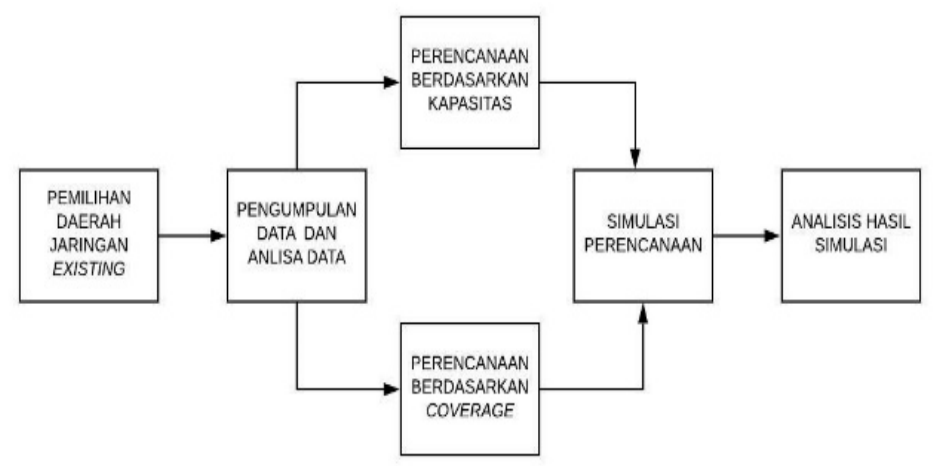

Gambar 1. Diagram blok sistem

Lokasi penelitian yang dipilih adalah Kota Tangerang Selatan, dimana Kota Tangerang Selatan merupakan sebuah kota yang terletak di tatar Pasundan Provinsi Banten, Indonesia. Luas 
wilayah Kota Tangerang Selatan sebesar 147,2 $\mathrm{Km}^{2}$ dan kepadatan penduduk mencapai 8.766 orang $/ \mathrm{Km}^{2}$. Kepadatan tertinggi terdapat di Kecamatan Ciputat Timur yaitu 11.589 orang/Km ${ }^{2}$ sedangkan kepadatan terendah di Kecamatan Setu yaitu 4.475 orang $/ \mathrm{Km}^{2}$.

\subsection{Proses Perencanaan Jaringan $4 G$}

Untuk mengetahui kondisi eksisting jaringan 4G LTE di Kota Tangerang Selatan dilakukan drive test. Drive test ini dilakukan dengan menggunakan aplikasi G-NetTrack Pro, dimana aplikasi ini dapat menampilkan nilai RSRP, SINR, RSRQ serta letak BTS sesuai provider yang digunakan saat drive test. Setelah dilakukan drive test, maka ditentukan spesifikasi untuk perencanaan ulang jaringan di daerah Kota Tangerang Selatan. Spesifikasi perencanaan ulang ditunjukkan pada tabel 1 .

Tabel 1. Spesifikasi Perencanaan 4G

\begin{tabular}{|l|l|}
\hline \multicolumn{1}{|c|}{ Spesifikasi } & \multicolumn{1}{c|}{ Jenis } \\
\hline Frekuensi & $1800 \mathrm{MHz}$ \\
\hline Bandwidth Frekuensi & $10 \mathrm{MHz}$ \\
\hline Resource Block & 50 \\
\hline Teknik Modulasi & 64 QAM \\
\hline Model Propagasi & COST 231 dan Lee \\
\hline
\end{tabular}

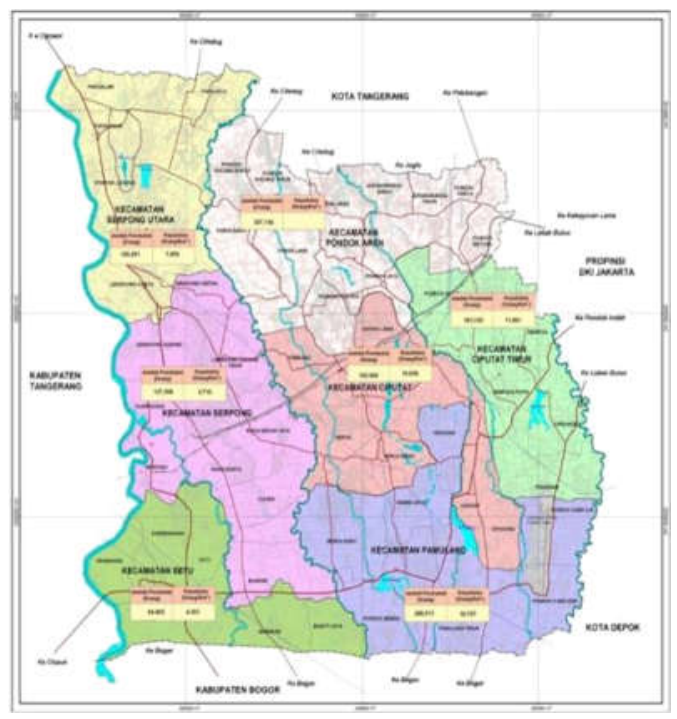

Gambar 2. Peta lokasi Kota Tangerang Selatan

\subsection{Perencanaan Jaringan 4G LTE Berdasarkan Kapasitas}

Perencanaan berdasarkan kapasitas menggunakan hasil perhitungan dari estimasi jumlah peduduk, estimasi jumlah pengguna seluler, perhitungan Single User Throughput (SUT), dan Network Troughput untuk menghitung jumlah sel yang diperlukan dalam perencanaan jaringan 4G di Kota Tangerang Selatan.

Jumlah pertumbuhan penduduk berpengaruh dalam perhitungan estimasi jumlah pelanggan seluler, kepadatan trafik, serta jumlah BTS yang akan ditambah. Untuk perhitungan estimasi jumlah pertumbuhan penduduk digunakan persamaan pertumbuhan geometrik, yaitu angka pertumbuhan penduduk sama setiap tahunnya seperti ditunjukkan pada persamaan (1)[3],

$$
P_{t}=P_{0}(1+r) t
$$

dengan $\mathrm{P}_{\mathrm{t}}$ adalah jumlah penduduk pada tahun ke-t, $\mathrm{P}_{\mathrm{o}}$ adalah jumlah penduduk pada tahun dasar, $\mathrm{r}$ merupakan laju pertumbuhan penduduk dan $\mathrm{t}$ adalah jangka waktu . 
Perhitungan Throughput digunakan untuk mengetahui kecepatan akses data yang diterima dari eNodeB menuju user equipment pada jam sibuk dan sesuai dengan daerah tertentu. Perhitungan Throughput per session ditunjukkan pada persamaan (2).

$$
\frac{\text { Throughput }}{\text { Session }}=\frac{\text { Bearer Rate } x \text { Session Time } x \text { Session Duty Ratio }}{1-B L E R}
$$

Hasil penjumlahan semua througput setiap layanan saat kondisi jam sibuk yang digunakan pada satu user adalah Single User Throughput (SUT). Untuk menghitung SUT menggunakan persamaan yang ditunjukkan pada persamaan (3), dan network throughput didapatkan dari service model dan data jumlah user yang digunakan pada daerah perencanaan[4]. Persamaan yang digunakan untuk menghitung Network Throughput ditunjukkan pada persamaan (4), dengan Busy Hour Attemmpt (BHSA) adalah jumlah akses layanan single user di jam sibuk, Penetration Rate adalah Proporsi penetrasi dari tipe layanan, Peak to Average Ratio (PAR) merupakan persentase lonjakan trafik.

$$
S U T=\frac{\left(\sum(\text { Throughput } x \text { BHSA } x \text { Penetration Rate })\right) x(1+\text { PAR })}{3600}
$$

Network Throughput $=$ Total Target User $x$ Single User Throughput (4)

Cell throughput biasa disebut cell capacity yang merupakan suatu cell yang dapat menangani kapasitas secara maksimal, dapat dihitung berdasarkan persamaan (5) dan (6).

$$
\begin{aligned}
& D L \text { Cell Capacity }+C R C=(168-36-12) \times(C b) \times(C r) \times N r b \times C \times 1000 \\
& U L \text { Cell Capacity }+C R C=(168-24-12) \times(C b) \times(C r) \times N r b \times C \times 1000
\end{aligned}
$$

Dengan mengetahui nilai network throughput dan cell throughput, jumlah sel yang dibutuhkan dapat dihitung dengan menggunakan persamaan (7).

$$
\text { Jumlah sel }=\frac{\text { Network Throughput }}{\text { Cell Throughput }}
$$

Luas cakupan sel diperoleh dari perhitungan Network Throughput per $\mathrm{km}^{2}$, dimana Network Throughput per $\mathrm{km}^{2}$ diperoleh dari hasil bagi antara nilai Network Throughput dengan luas wilayah perencanaan[5]. Kemudian luas sel dapat dihitung dengan menggunakan persamaan (9).

$$
\begin{gathered}
\text { Network Th roughput per } \mathrm{Km}^{2}=\frac{\text { Network Throughput }}{\text { Luas Wilayah }} \\
\text { Luas } \mathrm{Sel}=\frac{\text { Cell Throughput }}{\text { Network Throughput per } \mathrm{Km}^{2}}
\end{gathered}
$$

\subsection{Perencanaan Jaringan $4 G$ LTE Berdasarkan Coverage}

Perencanaan berdasarkan Coverage dilakukan dengan menghitung radius sel menggunakan 2 model propagasi yaitu cost 231 dan Lee, kemudian dilakukan simulasi menggunakan software ATOLL untuk mengetahui radius sel yang tercakup.

Untuk mengestimasi maksimum pelemahan sinyal yang diperbolehkan antara mobile antenna dan base station antenna dengan menghitung radio link budget. Nilai maksimum pelemahan sinyal ini disebut dengan Maximum Allowable Path Loss (MAPL)[6]. Nilai MAPL dapat dihitung menggunakan persamaan yang ditunjukkan pada persamaan (10) .

$$
M A P L=T_{X_{E I R P}}-T_{X_{E F S}}-L B V-M_{\text {interference }}-M S F
$$

dengan $\mathrm{T}_{\mathrm{xEIRP}}$ adalah effective isotropic radiated power dan $\mathrm{T}_{\mathrm{XEFS}}$ adalah effective Rx faded sensitivity. $\mathrm{LBV}$ adalah body vehicle building loss dan $\mathrm{M}_{\text {interference }}$ adalah margin interference serta MSF adalah log normal margin. 


\subsubsection{Model Propagasi Cost 231 Hatta}

COST 231 Hatta merupakan model propagasi hasil pengembangan dari model propagasi Okumura-Hata[7]. Coverage dari model COST 231 adalah dengan Frekuensi $1500-2000 \mathrm{MHz}$, ketinggian efektif antena transmitter $30-200 \mathrm{~m}$, ketinggian efektif antenna receiver adalah 1 $10 \mathrm{~m}$, jarak link (d) adalah $1-20 \mathrm{~km}$. Perhitungan pathloss pada model propagasi COST $231 \mathrm{ini}$ ditunjukkan pada persamaan (11).

$$
L_{50}(d B)=46,3+33,9 \log \left(f_{C}\right)-13,82 \log \left(h_{t}\right)-a\left(h_{r}\right)+\left[44,9-6,55 \log \left(h_{t}\right)\right] \log (d)+C
$$

\subsubsection{Model Propagasi Lee}

Model propagasi Lee diturunkan dari data eksperimen yang dilakukan di beberapa kota besar di dunia. Parameter referensi yang digunakan yaitu pada frekuensi $900 \mathrm{MHz}$, pada tinggi antena $30,5 \mathrm{~m}$ dengan daya transmisi $10 \mathrm{~W}$. Persamaan matematika model Lee ini ditunjukkan pada persamaan (12).

$$
L_{50}=L O+V \log d+F O
$$

Parameter pengukuran yang digunakan dalam perencanaan jaringan adalah nilai RSRP (Reference Signal Received Power) dan SINR(Signal Interference to Noise Ratio) [8], parameter RSRP dan SINR ditunjukkan pada Tabel 2 dan tabel 3. Untuk melihat kualitas performansi jaringan LTE dengan mengacu pada parameter Key Performance Indicator (KPI), seperti yang ditunjukkan pada tabel 4.

Tabel 2. Parameter RSRP [9]

\begin{tabular}{|l|c|}
\hline \multicolumn{1}{|c|}{ Category } & Range Nilai RSRP \\
\hline Very Good & $(-80) \leq \mathrm{x}$ \\
\hline Good & $(\leq-90) \mathrm{x}<(-80)$ \\
\hline Normal & $(\leq-100) \mathrm{x}<(-90)$ \\
\hline Bad & $(\leq-120) \mathrm{x}<(-100)$ \\
\hline Very Bad & $(<-120) \mathrm{x}$ \\
\hline
\end{tabular}

Tabel 3. Parameter SINR

\begin{tabular}{|l|c|}
\hline \multicolumn{1}{|c|}{ Category } & Range Nilai SINR \\
\hline Very Good & $(30) \geq x \geq(15)$ \\
\hline Good & $(15) \geq x \geq(0)$ \\
\hline Normal & $(0) \geq x \geq(-5)$ \\
\hline Bad & $(-5) \geq x \geq(-11)$ \\
\hline Very Bad & $(-11) \geq x \geq(-20)$ \\
\hline
\end{tabular}

Tabel 4. Parameter KPI [10]

\begin{tabular}{|l|l|l|}
\hline Objective & Parameter & Target KPI \\
\hline Integrity & Mean Throughput & $\geq 20 \mathrm{Mbps}$ \\
\hline Uji Coverage & RSRP & $80 \% \geq-80 \mathrm{dBm}$ \\
\hline Uji Kualitas Sinyal & SINR & $50 \% \geq 5 \mathrm{~dB}$ \\
\hline Accessibility & Blocked/rejected user & $<2 \%$ \\
\hline
\end{tabular}

\section{HASIL DAN PEMBAHASAN}

\subsection{Hasil Drive Test Pada Kondisi Eksiting Jaringan 4G LTE di Kota Tangerang Selatan}

Drive test jaringan kondisi eksisting dengan menggunakan aplikasi G-NetTrack Pro didapatkan nilai RSRP dan SINR seperti ditunjukkan pada gambar 3, nilai rata-rata RSRP dan SINR dan jumlah site yang terdapat di wilayah Kota Tangerang Selatan ditunjukkan pada tabel 5.

Tabel 5. Nilai rata-rata RSRP dan SINR

\begin{tabular}{|c|c|c|}
\hline $\begin{array}{c}\text { Nilai Rata-rata } \\
\text { RSRP }\end{array}$ & $\begin{array}{c}\text { Nilai Rata-rata } \\
\text { SINR }\end{array}$ & $\begin{array}{c}\text { Jumlah } \\
\text { Site }\end{array}$ \\
\hline$-108 \mathrm{dBm}$ & 3.0 & 46 site \\
\hline
\end{tabular}



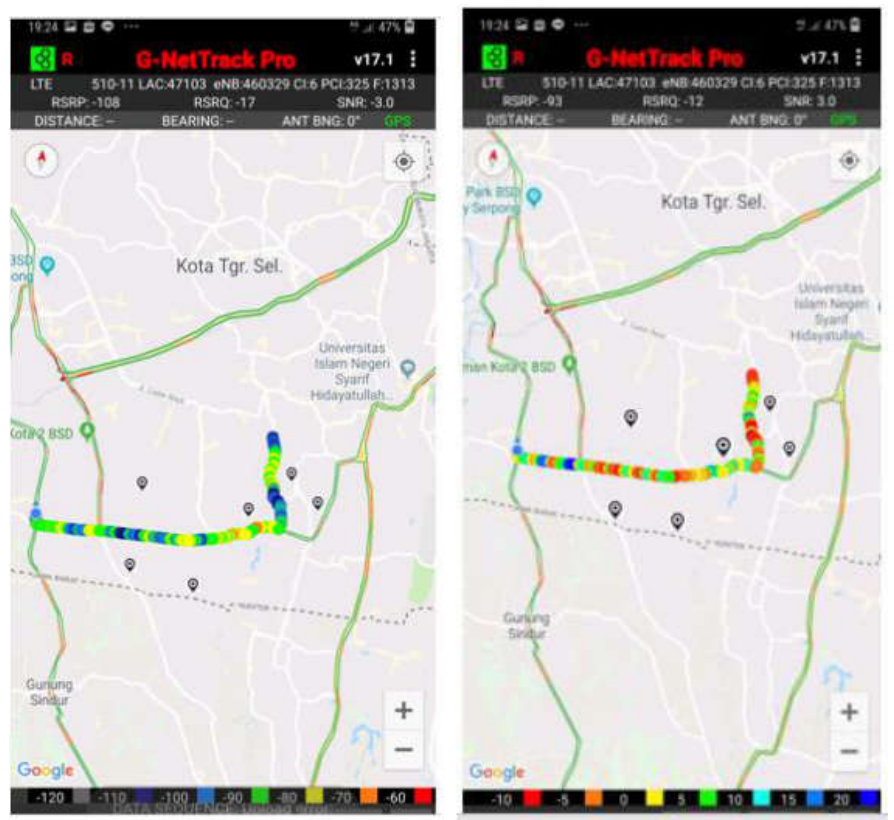

Gambar 3. Nilai RSRP dan SINR hasil drive test kondisi eksisting

Berdasarkan data pada tabel 5, nilai rata-rata RSRP termasuk dalam kategori buruk dan nilai rata-rata SINR termasuk dalam kategori normal. Hasil keseluruhan drive test yang dilakukan di Kota Tangerang Selatan didapatkan kondisi jaringan 4G operator XL Axiata masih dalam kategori buruk. Dari data tersebut dapat disimpulkan bahwa jaringan 4G XL Axiata di Kota Tangerang Selatan perlu dilakukan perencanaan ulang untuk mendapatkan kondisi jaringan $4 \mathrm{G}$ yang baik, serta dapat mencakup keseluruhan wilayah Kota Tangerang Selatan.

\subsection{Perencanaan Jaringan Berdasarkan Kapasitas}

Perencanaan berdasarkan kapasitas dimulai dengan perhitungan estimasi jumlah penduduk, estimasi jumlah pelanggan, kepadatan trafik, serta perhitungan jumlah sel yang dibutuhkan untuk 5 tahun kedepan dan perhitungan luas sel untuk mengetahui cakupan suatu sel.

Estimasi jumlah penduduk dan jumlah pelanggan seluler di Kota Tangerang Selatan direncanakan untuk tahun 2024. Data penduduk diambil pada tahun 2019 yang disusun oleh Badan Pusat Statistik Kota Tangerang Selatan. Data penduduk Kota Tangerang Selatan ditunjukkan pada tabel 6 [11].

Tabel 6. Data Penduduk Kota Tangerang Selatan tahun 2019

\begin{tabular}{|l|l|}
\hline Wilayah & Kota Tangerang Selatan \\
\hline Luas & $147,2 \mathrm{~km}^{2}$ \\
\hline Jumlah Penduduk tahun 2018 & 1.593 .812 Jiwa \\
\hline
\end{tabular}

Untuk mengetahui estimasi jumlah penduduk 5 tahun kedepan yaitu pada tahun 2024 dihitung menggunakan persamaan (1). Dari data Badan Pusat Statistik usia produktif (15-64 tahun) adalah $60 \%$ dari total jumlah penduduk tahun ke-t dan jumlah pengguna seluler diambil dari angka usia produktif. Berdasarkan data yang didapatkan dari Badan Pusat Statistik Kota Tangerang, jumlah penduduk dan jumlah pelanggan seluler kota Tangerang Selatan tahun 2019 dan tahun 2024 ditunjukkan pada tabel 7 [12].

Tabel 7. Estimasi Jumlah Penduduk dan Jumlah Pelanggan Seluler Tangerang Selatan

\begin{tabular}{|l|l|l|}
\hline \multicolumn{1}{|c|}{ Tahun } & \multicolumn{1}{|c|}{$\mathbf{2 0 1 9}$} & \multicolumn{1}{c|}{$\mathbf{2 0 2 4}$} \\
\hline Jumlah Penduduk Usia Produktif & 956.287 jiwa & 1.123 .749 jiwa \\
\hline Pengguna Seluler & 573.772 jiwa & 674.249 jiwa \\
\hline
\end{tabular}


Dengan menggunakan persamaan (2), nilai throughput/session untuk mengetahui kecepatan akses data dari eNodeB menuju user pada jam sibuk ditunjukkan pada tabel 8 .

Tabel 8. Hasil perhitungan Throughput

\begin{tabular}{|l|c|c|}
\hline \multirow{2}{*}{ Traffic Behavior } & Throughput/Session (kbps) \\
\cline { 2 - 3 } & Downlink & Uplink \\
\hline VOIP & 869.4949 & 869.4949 \\
\hline Video Conference & 113690.9 & 113690.9 \\
\hline Real Time Gaming & 11367.27 & 90952.73 \\
\hline Streaming Media & 5683.636 & 864016.4 \\
\hline IMS Signalling & 22.10303 & 22.10303 \\
\hline Web Browsing & 5684.545 & 22737.27 \\
\hline File Transfer & 85266.67 & 454751.5 \\
\hline Video Phone & 4421.313 & 4421.313 \\
\hline Email & 7105.556 & 11368.79 \\
\hline P2P File Sharing & 303163.6 & 909575.8 \\
\hline
\end{tabular}

Network Throughput didapatkan dari service model dan data jumlah user yang digunakan pada daerah perencanaan. Hasil perhitungan Network Throughput dan Cell Throughput ditunjukkan pada tabel 9. Setelah dilakukan perhitungan Network Throughput dan Cell Capacity maka dapat dihitung jumlah sel yang dibutuhkan dalam perencanaan berdasarkan kapasitas.

Tabel 9. Hasil Perhitungan Network Throughput dan Cell Throughput

\begin{tabular}{|l|c|c|}
\hline & Uplink & Downlink \\
\hline Network Throughput (Mbps) & 3910 & 14429 \\
\hline Cell Capacity (Mbps) & 37 & 36 \\
\hline
\end{tabular}

Berdasarkan data downlink pada tabel 9, jumlah sel yang dibutuhkan dengan bandwidth $10 \mathrm{Mhz}$ adalah :

$$
\begin{aligned}
\text { Jumlah sel } & =\frac{14429 \mathrm{Mbps}}{36 \mathrm{Mbps}} \\
& =144
\end{aligned}
$$

Dengan jumlah sel 144, maka didapatkan jumlah site sebesar :

$$
\begin{aligned}
\text { Jumlah Site } & =144: 3 \\
& =48 \text { Site }
\end{aligned}
$$

Perhitungan luas sel untuk mengetahui cakupan sel yang akan disimulasikan dengan melakukan perhitungan Network Throughput per $\mathrm{km}^{2}$, kemudian dilakukan perhitungan luas sel atau luas cakupan sel. Berdasarkan nilai network throughput, didapatkan Network Throughput per $\mathrm{km}^{2}$ :

$$
\begin{aligned}
\text { Network Throughput per } \mathrm{Km}^{2} & =\frac{\text { Network Throughput }}{\text { Luas Wilayah }} \\
& =\frac{14429}{147,2}=98
\end{aligned}
$$

Maka luas sel didapatkan sebesar:

$$
\begin{aligned}
\text { Luas sel } & =\frac{\text { Cell Throughput }}{\text { Network Throughput per } \mathrm{km}^{2}} \\
\text { Luas sel } & =\frac{37}{98} \\
& =0,37 \mathrm{Km}^{2}
\end{aligned}
$$

Setelah dilakukan perhitungan, maka dilakukan perencanaan ulang menggunakan software ATOLL dengan menggunakan parameter RSRP dan SINR. Hasil simulasi perencanaan ulang berupa cakupan site, dan rata - rata nilai SINR dan RSRP ditunjukkan pada gambar 4. 


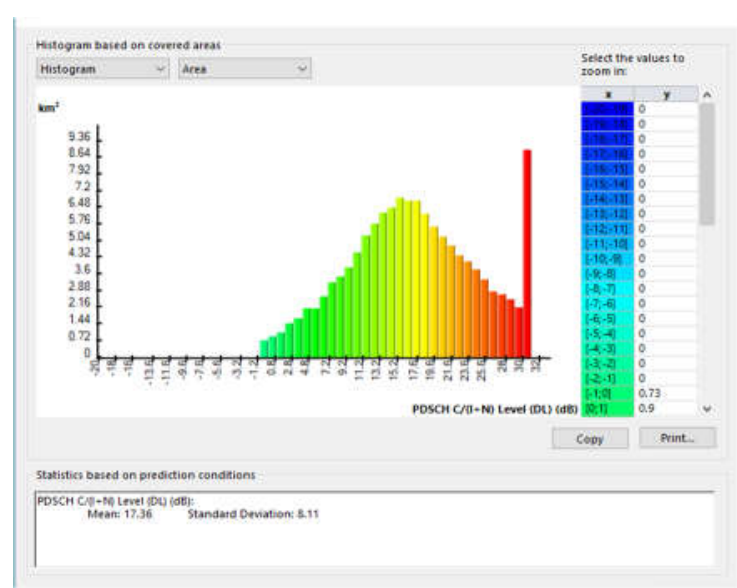

(a) SINR

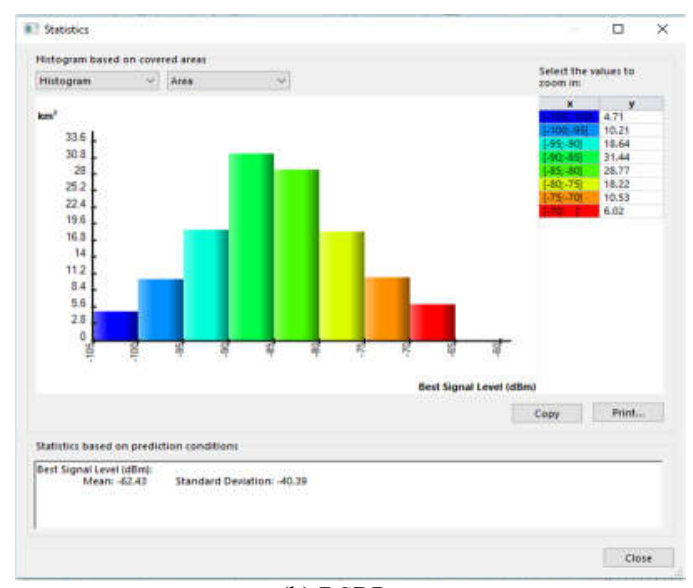

(b) RSRP

Gambar 4. Nilai RSRP dan SINR hasil simulasi

\subsection{Perencanaan Jaringan Berdasarkan Coverage}

Perencanaan berdasarkan coverage ini dimulai dengan perhitungan Maximum Allowable Path Loss (MAPL), kemudian perhitungan radius sel menggunakan 2 model propagasi yaitu model Cost 231 Hatta dan model Lee. Tabel 10 menunjukkan nilai MAPL berdasarkan parameter dari sisi downlink dengan nilai $147,8 \mathrm{~dB}$, nilai tersebut dapat digunakan untuk mengetahui radius sel dari sisi coverage. Nilai MAPL dari sisi uplink dengan nilai $128 \mathrm{~dB}$, digunakan untuk perhitungan radius sel dengan menggunakan model propagasi

Tabel 10. Link Budget Downlink dan Uplink

\begin{tabular}{|l|c|c|c|}
\hline \multicolumn{1}{|c|}{ Parameter } & Kalkulasi & Link Budget Downlink & Link Budget Uplink \\
\hline EIRP (Effective Isotropic Radiated Power) & A & $64 \mathrm{~dB}$ & $30 \mathrm{~dB}$ \\
\hline Effective Rx Faded Sensitivity & B & $-102.3 \mathrm{dBm}$ & $-116.5 \mathrm{dBm}$ \\
\hline Body, Vehicle, Building Loss & C & $10 \mathrm{~dB}$ & $10 \mathrm{~dB}$ \\
\hline Interference Margin & D & $2 \mathrm{~dB}$ & $2 \mathrm{~dB}$ \\
\hline Log Normal Margin & E & $6.5 \mathrm{~dB}$ & $6.5 \mathrm{~dB}$ \\
\hline MAPL & F = A-B-C-D-F & $147.8 \mathrm{~dB}$ & $128 \mathrm{~dB}$ \\
\hline
\end{tabular}

\subsubsection{Propagasi COST 231-Hatta}

Perhitungan model propagasi Cost 231- Hatta dilakukan untuk mengetahui jangkauan site dalam penyebaran jaringan 4G. Untuk mengetahui jangkauan site, maka perlu nilai maksimum path loss yang sudah di hitung di tabel 10, sehingga akan didapat diameter site.

Tabel 11. Luas sel dan jumlah site hasil perhitungan Cost 231

\begin{tabular}{|l|l|}
\hline Luas Sel & $20,28 \mathrm{Km}^{2}$ \\
\hline Jumlah Site & 7 Site \\
\hline
\end{tabular}

Setelah perhitungan model propagasi cost 231 untuk mengetahui jangkauan sel, maka dapat dilakukan simulasi melalui Atoll untuk mengetahui nilai rata-rata SINR dan RSRP. Histogram dari hasil simulasi menggunakan model propagasi cost 231 ditunjukkan pada gambar 5, dihasilkan nilai rata-rata SINR sebesar 6,23 dB dengan standar deviasi 4,66 dB. Jika dilihat dari parameter SINR hasil tersebut termasuk dalam kategori baik dan sudah sesuai dengan parameter KPI. 


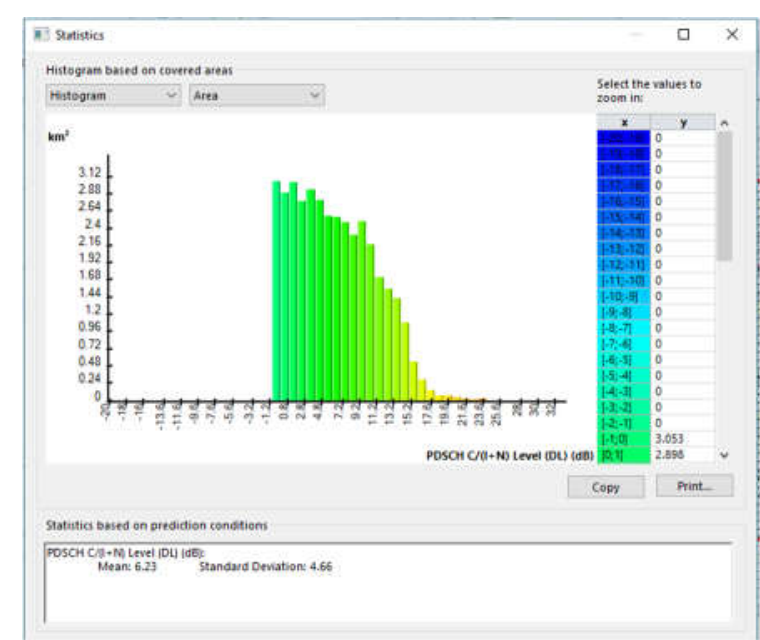

(a) Nilai rata-rata SINR

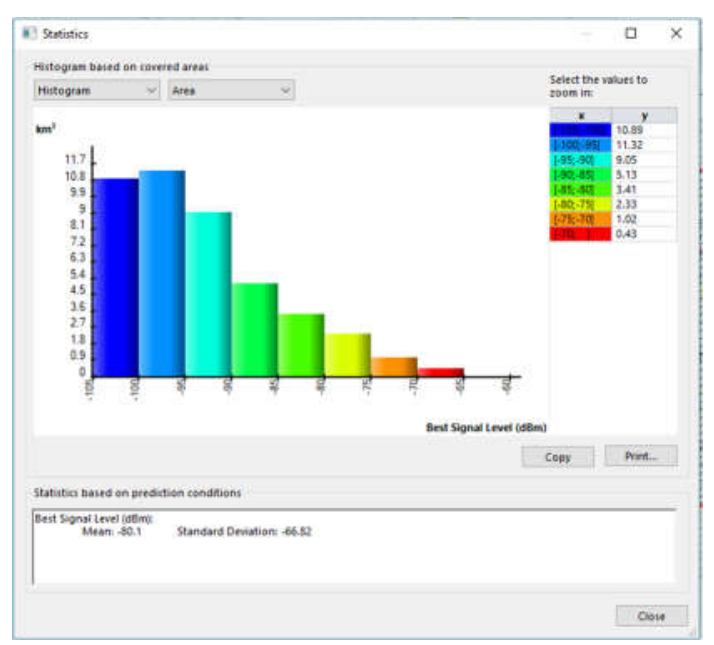

(b) Nilai rata-rata RSRP

Gambar 5. Nilai rata-rata SINR dan RSRP model Propagasi Cost 231

\subsubsection{Propagasi Lee}

Pada model propagasi Lee dapat dihitung jangkauan site berdasarkan coverage dengan menggunakan nilai maksimum loss sebagai parameter. Luas sel dan jumlah site hasil perhitungan model propagasi Lee ditunjukkan pada tabel 12 .

Tabel 12. Luas sel dan jumlah site hasil perhitungan Lee

\begin{tabular}{|l|l|}
\hline Luas Sel & $316 \mathrm{Km}^{2}$ \\
\hline Jumlah Site & 0,4 site $\approx 1$ Site \\
\hline
\end{tabular}

Berdasarkan hasil perhitungan link budget serta perhitungan model propagasi Lee, untuk mengetahui nilai RSRP dan SINR serta cakupan tiap site maka dilakukan simulasi menggunakan Atoll. Nilai rata-rata SINR dan RSRP untuk model propagasi Lee dengan simulasi Atoll, hasilnya ditunjukkan pada gambar 6 .

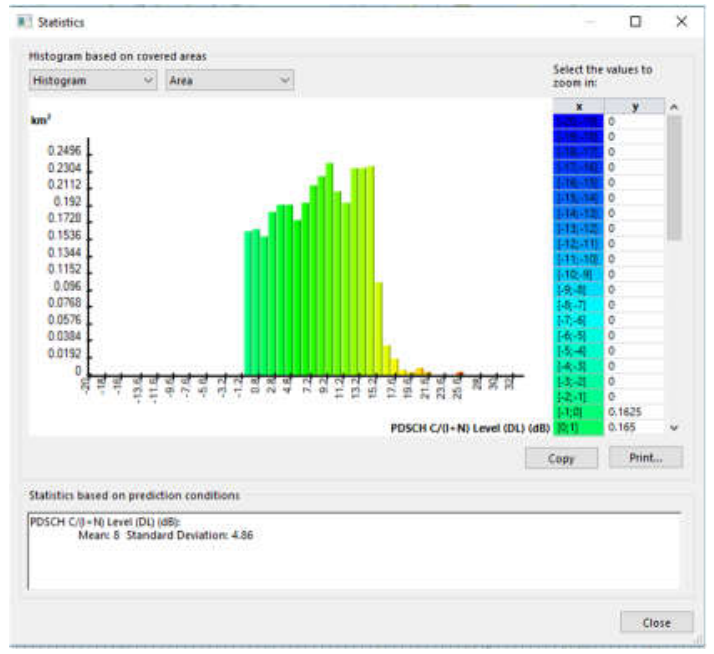

(a) Nilai SINR

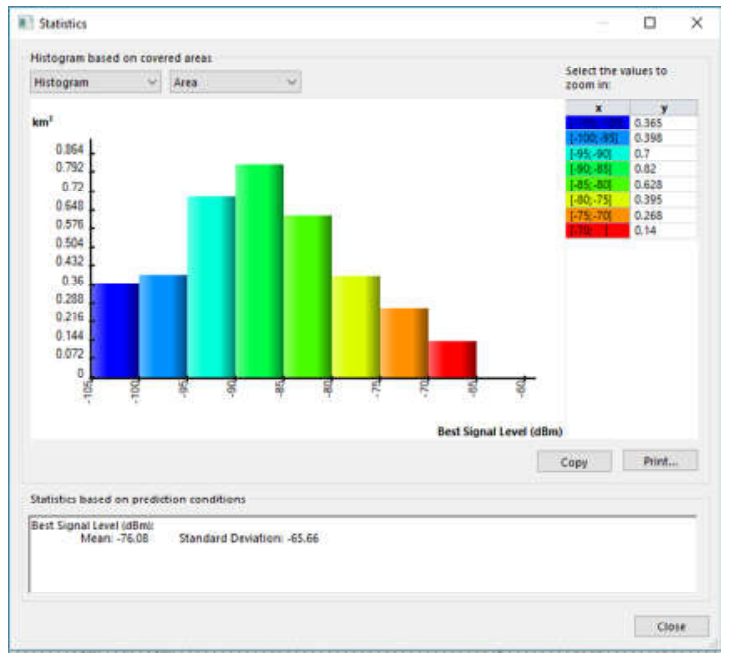

(b) Nilai RSRP

Gambar 6. Nilai SINR dan RSRP model Propagasi Lee

Setelah dilakukan simulasi perencanaan ulang jaringan 4G LTE di Kota Tangerang Selatan dengan klasifikasi daerah Suburban menggunakan ATOLL, didapatkan model propagasi yang cocok untuk daerah suburban.

Berdasarkan hasil perhitungan dan simulasi, nilai yang terbaik adalah model propagasi Lee, karena 1 site bisa mencakup area sebesar 7,9 Km dengan nilai rata - rata SINR $8 \mathrm{~dB}$ termasuk kategori baik dan nilai RSRP yang dihasilkan $-76,08 \mathrm{dBm}$ termasuk kategori sangat baik. Dapat 
disimpulkan bahwa model propagasi yang sesuai untuk perencanaan ulang di Kota Tangerang Selatan ini adalah model propagasi Lee.

Tabel 13. Perbandingan Model Propagasi Cost 231 dengan Lee

\begin{tabular}{|l|c|c|}
\hline \multicolumn{1}{|c|}{ Jenis Analisa } & Model Propagasi Cost 231 & Model Propagasi Lee \\
\hline Jangkauan Site & $2 \mathrm{Km}$ & $7,9 \mathrm{Km}$ \\
\hline Jumlah Penambahan Site & $7 \mathrm{buah}$ & $1 \mathrm{buah}$ \\
\hline Nila rata - rata SINR & $6,23 \mathrm{~dB}$ & $8 \mathrm{~dB}$ \\
\hline Nilai rata - rata RSRP & $-80,01 \mathrm{dBm}$ & $-76,08 \mathrm{dBm}$ \\
\hline
\end{tabular}

\subsection{Perbandingan antara Base Transciever Station (BTS) Drive Test dan Simulasi Model} Propagasi Cost 231.

Setelah dilakukan beberapa kali simulasi, maka dapat dibandingkan nilai RSRP dan SINR dari salah satu BTS antara hasil drive test dengan hasil simulasi menggunakan model propagasi Cost 231.

Untuk membandingkan BTS, digunakan salah satu BTS dari seluruh hasil drive test (sebelum perencanaan).

Tabel 14. Kondisi Site dari Hasil drive test

\begin{tabular}{|l|l|l|l|l|}
\hline Longitude & Latitude & Side & RSRP & SINR \\
\hline 106,7444 & $-6,27399$ & 470120 & $-103 \mathrm{dBm}$ & $-5 \mathrm{~dB}$ \\
\hline
\end{tabular}

Dari Tabel 14 terdapat nilai RSRP dan SINR termasuk dalam kategori sangat buruk, serta tidak sesuai dengan parameter KPI.

Hasil simulasi berdasarkan coverage menggunakan model propagasi Cost 231 dilakukan simulasi untuk salah satu site saja, site yang digunakan adalah site 6 dengan longitude 106,7444 dan latitude $-6,273399$. Hasil simulasi nilai RSRP dan SINR site 6 COST 231 ditunjukkan pada gambar 7 dan 8 .

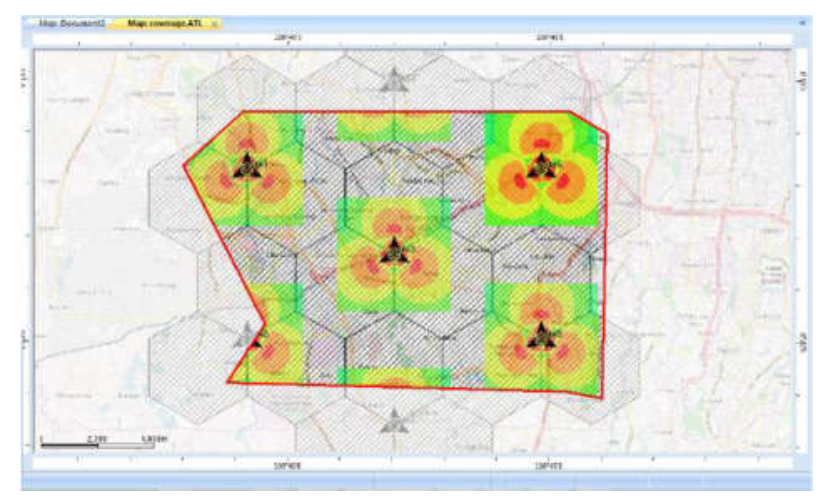

Gambar 7. Hasil Simulasi RSRP Site ke-6 COST 231

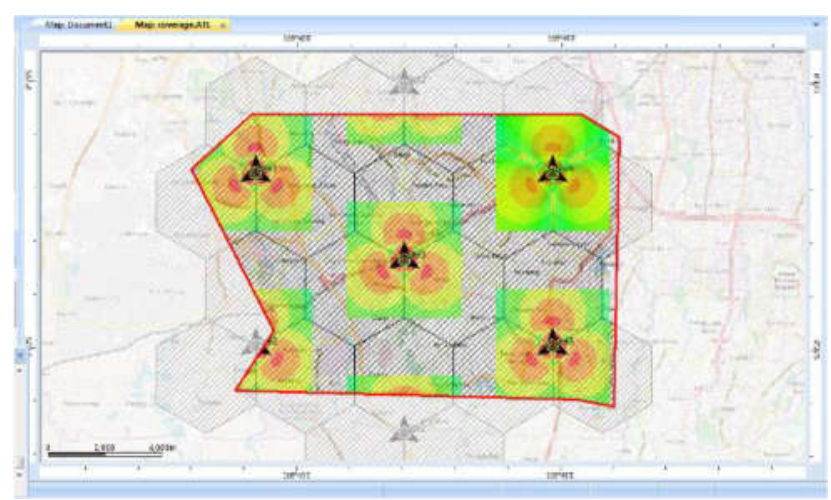

Gambar 8. Hasil Simulasi SINR Site ke-6 COST 231

Hasil perbandingan BTS sebelum perencanaan (hasil drive test) dan setelah perencanaan 
(simulasi) ditunjukkan pada tabel 15. Dapat disimpulkan kondisi BTS setelah perencanaan lebih baik dari sebelum perencanaan. Kondisi BTS hasil drive test nilainya buruk, namun setelah dilakukan perencanaan ulang dan simulasi kondisi BTS sudah termasuk dalam kategori sangat baik, maka dapat dikataakan perencanaan ulang yang dilakukan berhasil.

Tabel 15. Perbandingan BTS sebelum perencanaan dan setelah perencanaan

\begin{tabular}{|l|c|c|}
\hline & Drive Test (sebelum perencanaan) & Simulasi (setelah perencanaan) \\
\hline Longitude & 106,7444 & 106,7444 \\
\hline Latitude & $-6,273399$ & $-6,273399$ \\
\hline Site & 470120 & Site ke-6 \\
\hline RSRP & $-103 \mathrm{dBm}$ & $-75 \mathrm{dBm}$ \\
\hline SINR & $-5 \mathrm{~dB}$ & $9,82 \mathrm{~dB}$ \\
\hline
\end{tabular}

\section{KESIMPULAN}

Berdasarkan hasil yang didapatkan dari perencanaan jaringan 4G LTE di Kota Tangerang Selatan pada eNode B, perencanaan berdasarkan kapasitas didapatkan jumlah eNode B 4G pada tahun 2024 adalah 48 Site dengan luas cakupan $0,37 \mathrm{Km}^{2}$. Hasil simulasi berdasarkan Kapasitas nilai SINR dan RSRP yang dihasilkan termasuk kategori sangat baik. Dari hasil perhitungan dan simulasi dari perencanaan berdasarkan coverage model propagasi yang sesuai untuk digunakan di Kota Tangerang Selatan adalah model propagasi Lee, nilai SINR dan RSRP termasuk dalam kategori Baik.

\section{DAFTAR PUSTAKA}

[1] M. R. Fauzi and T. Prakoso, 2015, Perencanaan Jaringan LTE FDD 1800 MHZ Di Kota Semarang Menggunakan ATOLL, Transient, No.3, Vol.4, September.

[2] R. Q. Shaddad and N. Y. Saleh, 2018, Planning and Optimization of LTE Radio Access Network for Suburban and Rural Area at Taiz City, Yemen, Proceeding : International Conference of Reliable Information and Communication Technology, pp. 440-450.

[3] M. Ulfah and F. F. Kurnia, 2018, Penentuan Jumlah eNodeB Jaringan 4G/LTE Di Kecamatan Penajam Kabupaten Penajam Paser Utara, J. Surya Energy, No. 2, Vol. 2, pp. 179-184. Maret.

[4] A. Wahyudin and Sakinah, 2016, Perancangan dan Analisa Penggelaran LTE Pada Frekuensi $700 \mathrm{MHz}$ Dengan Metode Adaptif Modulation Coding Untuk Implementasi Digital Dividend di Wilayah Sub-urban dan Rural Kabupaten Banyumas, JETT : Jurnal Elektro Telekomunikasi Terapan, pp. 342-354.

[5] R. Nlend and E. Tonye, 2019, Planning and simulation of LTE radio network : case of the city of Yaoundé, IOSR J. Electron. Commun. Eng., No. 2, Vol. 4, pp. 19-29.

[6] S. Rahmatia, A. A. Azzahra, M. Ismail, O. N. Samijayani, and D. Astharini, 2018, Long Term Evolution (LTE) Network Design Frequency Division Duplex (FDD) of $1800 \mathrm{MHz}$ Based on Subscriber Growth Forecasting in 2025 at Denpasar, Indonesia, IEEE 5th International Conference on Engineering Technologies and Applied Sciences (ICETAS).

[7] A. Mardhatillah, R. Munadi, and H. Walidainy, 2018, Perencanaan Jaringan Long Term Evolution (LTE) Menggunakan Model Propagasi Cost 231 Hata di Kota Sabang, KITEKTRO J. Online Tek. Elektro, Vol. 3, pp. 17-21.

[8] A. Hikmaturokhman and A. R. Danisya, 2017, 4G-LTE $1800 \mathrm{Mhz}$ coverage and capacity network planning using frequency reuse 1 model for rural area in Indonesia, ICSCA : Proceedings of the 6th International Conference on Software and Computer Application.

[9] M. Tahalani and R. V. Sathya, 2014, Optimal Femto Placement in Enterprise Femtocell Networks, IEEE Int. Conf. Adv. Networks Telecommuncations System. 
[10] A. C. U. Putri, U. K. Usman, and S. P. W. Jarot, 2017, Analisis Optimasi Coverage Jaringan Long Term Evolution (LTE) TDD Pada Frekuensi $2300 \mathrm{MHz}$ di Wilayah DKI Jakarta, Semininar Nasional. Inovasi Dan Apl. Teknol. di Indonesia.

[11] Badan Pusat Statistik Kota Tangerang Selatan, 2019, Kecamatan Pamulang Dalam Angka 2019, https://tangselkota.bps.go.id/publication/download.html, diaksses tanggal 15 April 2019.

[12] Badan Pusat Statistik Kota Tangerang Selatan, 2019, Kecamatan Serpong Dalam Angka 2019, https://tangselkota.bps.go.id/publication/download.html, diakses tanggal 15 April 2019. 